\title{
$\Delta 1$ Presença do Religioso no Espaço PÚBlico: MODAlidAdes NO BRASIL
}

Emerson Giumbelli

Este artigo apresenta idéias e análises que demandam aprofundamento e debate. Procuro tomar uma constatação enquanto desafio: como entender, no Brasil, a presença legitimada da religião no espaço público? Procederei tratando das formas que permitiram essa presença por meio de definições históricas que tomaram por referência universos sociais diversos. Assim, inicio com o catolicismo, passo pelo espiritismo e pelos cultos afro-brasileiros, e termino com os evangélicos. Embora esses termos correspondam aos segmentos que nos acostumamos a reconhecer no campo religioso brasileiro, a questão é exatamente saber sob qual definição de religião foi possível acolhê-los no espaço público. Essa acolhida corresponde a alguma forma de reconhecimento da religião por meio de dispositivos jurídicos que implicam o aparato e o poder de Estado e que envolvem algum grau de legitimidade social. Aposto então que as relações entre Estado e religião no Brasil ficam mais inteligíveis se adotamos essa perspectiva histórica capaz de constatar as operações que produzem modos de presença.

Reforço o sentido do termo "constatação". Não se trata, em primeiro lugar, de considerar isso um "problema", como a coisa parece se tornar quando é assumida a perspectiva que interpreta a situação brasileira iluminada pelo paradigma da secularização. A constatação, nesse caso, refere-se ao fato de que certas formas de presença da religião no espaço público não foram construídas 
por oposição à secularização, mas, por assim dizer, no seu interior. Em outras palavras, foi no interior da ordem jurídica encimada por um Estado comprometido com os princípios da laicidade que certas formas de presença da religião ocorreram. Em segundo lugar, tampouco é o caso de deixar de problematizar essa situação, o que acaba sendo o efeito de muitas análises que se contentam em destacar a ininterrupta vitalidade do campo religioso brasileiro. Não se pode eludir que essa vitalidade, em algumas das suas dimensões, depende de um diálogo com os mecanismos de reconhecimento ensejados por aquelas formas de presença. Desprezá-las significa deixar de apreender alguns dos vetores de historicidade da constituição de qualquer campo religioso - o que nos conduz novamente ao tema da laicidade (ou do secularismo), à referência que ele encarna na conexão com o "Ocidente", e à necessidade de qualificá-la em qualquer situação em que apareça.

A perspectiva que procuro assumir segue de perto as idéias de Talal Asad, antropólogo saudita-britânico radicado nos Estados Unidos ainda pouco conhecido no Brasil. Depois de formular uma crítica a definições universalistas de religião (Asad 1993), o mesmo autor propôs uma "antropologia do secularismo", na qual este é entendido como parte da modernidade (Asad 2003). Ao meu ver, o verdadeiro objeto de Asad é exatamente a modernidade de raiz ocidental, concebida tanto como projeto que busca institucionalizar alguns princípios (secularismo ou laicidade, entre eles), quanto como conjunto de tecnologias que produzem "sensibilidades, estéticas e moralidades distintivas" (Asad 2003:14). Nesse projeto e nessas tecnologias, o Estado-nação e seu aparato legal são um elemento crucial, enfocado em seu papel de formador dos sujeitos-cidadãos. "Secular" e "religioso" constituem pares indissociáveis na modernidade, e o que se trata de fazer, para Asad, é “problematizar 'o religioso' e 'o secular' como categorias claramente diferenciadas, mas também investigar as condições nas quais essa diferenciação é afirmada e sustentada como tal” (Asad 2006a:298). Assim, é possível constatar acomodações de agentes religiosos em Estados seculares, mas também definições seculares do religioso. Ou, como ele demonstra ao analisar alguns desenvolvimentos da controvérsia sobre o véu em escolas francesas, apontar a atribuição secular de motivações religiosas (Asad 2006b). Seja como for, a presença do religioso na sociedade está sempre relacionada com os dispositivos estatais, apesar ou por causa da laicidade.

No Brasil, em se tratando de laicidade, nos deparamos com a aurora republicana como marco. É quando se adota de modo assumido o princípio da separação entre Estado e igrejas. Em termos mais concretos: rompe-se com o arranjo que oficializava e mantinha a Igreja Católica; o ensino é declarado leigo, os registros civis deixam de ser eclesiásticos, o casamento torna-se civil, 
os cemitérios são secularizados; ao mesmo tempo, incorporam-se os princípios da liberdade religiosa e da igualdade dos grupos confessionais, o que daria legitimidade ao pluralismo espiritual. Note-se que estamos no final do século XIX e a amplitude desse projeto de laicização coloca o Brasil ao lado, e mesmo à frente, de outros países igualmente comprometidos com aqueles princípios. Mas como eles foram concretizados? Levantar tal questão implica em apostar na seguinte idéia: mais do que princípios, o que estão em jogo são dispositivos que configuram a relação entre Estado e religião dentro das exigências da laicidade, partindo-se da constatação de que esse modelo é adotado simultaneamente em muitas nações. Ou seja, temos muitos experimentos de laicidade naquele momento histórico e não precisamos, para entendê-los, sujeitar a maioria deles a um referencial analítico decalcado de alguma situação nacional particular. ${ }^{2}$

Por muitas razões, a Igreja Católica teve um papel crucial na definição do novo regime de relações entre Estado e religião no Brasil republicano. Ressaltase bastante o fato de que a Igreja Católica foi contrária à sua separação com o Estado. E é fácil de mostrar como seus líderes e representantes se empenharam na defesa do regime contrário ou de algum tipo de reconhecimento, por parte do Estado, da preeminência do catolicismo na constituição da nacionalidade. Tais empenhos foram em parte recompensados no texto da Constituição de 1934, na qual, por exemplo, o ensino religioso é permitido e o casamento religioso volta a ter validade civil; além disso, o princípio da separação é temperado pela possibilidade de "colaboração" entre Estado e religiões ${ }^{3}$. A noção de "colaboração" conferiu assim um fundamento constitucional para aproximações entre Estado e religiões, o que, naquele momento histórico, traduziu as vitórias conquistadas pela Igreja Católica. Mas não devemos exagerar as implicações dessa noção, ratificada até o presente, ${ }^{4}$ pois sua formulação a manteve subordinada ao princípio da separação e ela não gerou ou se atrelou a nenhum dispositivo jurídico específico. Na verdade, ela veio a oficializar aproximações que já se faziam dentro do regime constitucional anterior - e desde seus inícios. ${ }^{5}$

Mais importante em suas implicações, ao meu ver, foi a definição que se conferiu ao princípio da "liberdade religiosa". E, nesse caso, é imperativo destacar que a mesma Igreja Católica que foi contra a separação se colocou a favor da liberdade. A traduzir o princípio, estavam em jogo discussões sobre a autonomia jurídica das associações religiosas. A lei de 1890 que produziu a separação entre Estado e Igreja Católica reconhecia a "todas as igrejas e confissões religiosas" "a personalidade jurídica para adquirirem os bens e os administrarem", mas "sob os limites postos pelas leis concernentes à propriedade de mão-morta" (art. 5ํ.). Já na Constituição de 1891, venceu a seguinte formulação, com o apoio das forças católicas: "Todos os indivíduos e confissões religiosas podem exercer publicamente o seu culto, associando-se para esse fim e adquirindo bens, observadas as disposições do direito comum" (art. 72 §3). No entanto, mesmo 
depois disso, a diretriz seguida pelas autoridades ministeriais era no mínimo hesitante, pois houve iniciativas no sentido de limitar ou desautorizar operações econômicas realizadas por instituições católicas. Seguiu-se então um debate jurídico de conseqüências importantes para a definição do regime de constituição dos coletivos religiosos no Brasil, no qual a Igreja Católica interveio ao mesmo tempo em que se preocupava em reorganizar a articulação das suas partes para se tornar uma entidade mais coesa do que era antes.

Desse debate jurídico, não posso senão destacar os principais resultados ${ }^{6}$. Estava em jogo, repito, a definição sobre a autonomia jurídica das associações religiosas. Havia quem achasse que o Estado deveria manter prerrogativas sobre algumas das dimensões econômicas da vida dessas associações, sobretudo a aquisição e alienação de bens. Ao mesmo tempo, não estava claro como as associações religiosas ficariam conferidas de personalidade jurídica, e de que tipo ela seria. Na busca de resposta para essas questões, ganham destaque, por sua importância no ordenamento jurídico do país, as estipulações do Código Civil que passa a vigorar em 1917. No entanto, elas reafirmam o que já tinham estabelecido as provisões de uma lei de 1893. Três pontos são essenciais: (i) não pesa nenhuma restrição específica sobre a vida econômica das associações religiosas, cabendo aos seus estatutos estipular as formas de gestão, relação entre membros e os objetivos do coletivo; (ii) as associações religiosas ganham personalidade jurídica pelo registro civil de seu estatuto, o que independe de qualquer autorização prévia; (iii) as associações religiosas estão submetidas ao mesmo regime civil das outras sociedades sem fins lucrativos, sem corresponder a uma figura jurídica distinta e própria.

Essa configuração ensejou, ainda em 1893, o comentário, publicado em francês, de que se consagrou no Brasil um entendimento de que não existiria nenhum limite ou controle estatal em relação às associações religiosas (Souza Bandeira 1893). De fato, construiu-se um fundamento jurídico para conferir personalidade aos coletivos religiosos, o que significava reconhecer sua existência e ação legais em várias esferas, sem nenhuma restrição específica aos seus atos civis. A liberalidade é reforçada pela ausência de uma figura jurídica específica, embora, como veremos adiante, as entidades religiosas não tenham permanecido totalmente indiferenciadas. Por outro lado, o arranjo estabelecido não significava ausência de restrições. A lei de 1893, por exemplo, menciona a proibição de fins ou meios "ilícitos" ou "imorais". Mais importante era a idéia tácita de que os coletivos religiosos teriam as condições para se auto-regularem de modo a se manterem dentro dos limites das leis e da "moralidade". Não se pode esquecer também que o ordenamento jurídico se construía de modo a regulamentar outras esferas, das quais - obedecendo a uma das expectativas da modernidade a que tal ordenamento aderia - a religião deveria estar ausente. Assim, um regime de poucas restrições e especificações sobre as associações religiosas - 
como queria a Igreja Católica - precisa ser entendido no quadro que articula uma expectativa de auto-regulação e uma regulação indireta do domínio religioso.

Isso nos conduz a outro plano do reconhecimento estatal do religioso no Brasil. Todo o debate que desemboca no Código Civil de 1917, como já havia formulado em outro texto, "versou quase nunca sobre a 'religião' que teria 'liberdade', quase sempre sobre a 'liberdade' de que desfrutaria a 'religião'” (Giumbelli 2002:276). Ou seja, sua referência era a Igreja Católica e um catolicismo eclesial, sobre os quais não havia dúvidas sobre seu estatuto de "religião". É muito interessante constatar que, contemporaneamente, ocorria aí sim um debate sobre a aplicabilidade do conceito de religião aos cultos que a literatura acadêmica chama de mediúnicos. Esse debate remetia às questões da saúde pública, um domínio que na passagem do século XIX para o XX mobilizou regulamentações massivas e pretendeu figurar como principal dimensão da vida comum. Sua repercussão sobre o domínio religioso serve como ilustração do argumento acerca da regulação indireta, o que possibilitava a convivência entre liberdade e restrição do alegadamente religioso. A principal base remetia ao Código Penal, outra legislação dos inícios da República, que trazia dispositivos que criminalizavam a prática do "espiritismo" e a da "magia e seus sortilégios" (art. 157). Esse dispositivo ladeava outros que visavam a prática da medicina por indivíduos desprovidos de título acadêmico e o exercício do "curandeirismo". Tal base jurídica serviu de referência para elaborações e intervenções de alto impacto social, assim como para reações importantes em se tratando de reconfigurações de formas de presença do religioso.?

O Código Penal, juntamente com regulamentações sanitárias e policiais, fundamentou ações que atingiram sobretudo cultos que, por suas referências africanas, eram identificados como claramente "mágicos", em um sentido que se traduzia em "selvageria" e "feitiçaria". Mas, ao menos na capital da República, foram os espíritas, cujas práticas mediúnicas estavam orientadas pela obras de Allan Kardec, os que se destacaram na reação ao que viam como uma contradição entre o Código Penal de 1890 e a Constituição de 1891. Sua reação foi também motivada por incursões policiais e judiciárias ao seu universo institucional. Essas incursões interpelavam as práticas terapêuticas que se desenvolveram com bastante força no espiritismo, desde seu ingresso no Brasil em meados do século XIX. A resposta dos porta-vozes espíritas aos ataques - em defesas judiciais, em manifestações na imprensa - enfatizou o enquadramento de suas práticas à noção de "religião". Para tanto, a categoria "caridade" foi crucial. A cura proporcionada por meios mediúnicos - argumentavam os espíritas -, a que acorriam livremente os mais diversos indivíduos, tinha como meio e como fim a caridade. Não esperava pagamento de qualquer tipo como contrapartida material e significava o exercício de um princípio inerente e necessário à religião professada. 
Pode-se dizer que esse argumento teve êxito, no sentido de garantir uma margem de imunidade a práticas terapêuticas que reclamam motivação religiosa. Essa constatação, contudo, deve vir acompanhada de outras duas. De um lado, o Estado conservou o princípio que oficializa, em tese, o monopólio da cura à medicina acadêmica; de outro, no universo das práticas "espíritas", predominou um vetor que produziu uma adequação, também em tese, das terapêuticas a intervenções “espirituais". Na prática, porém, é considerável o espaço para o desenvolvimento e a oferta de "terapias espirituais", sobretudo sob estatuto de informalidade e sem a sua penetração nos espaços da medicina acadêmica. Em relação à questão das formas de presença do religioso, pode-se afirmar que o argumento espírita da caridade produziu uma extensão da modalidade moldada a partir do argumento católico da liberdade. Em outras palavras: é legítimo que essas pessoas que são as associações religiosas desenvolvam terapêuticas "espirituais" cuja presença no espaço público, se não aceita, é bastante tolerada. Lembre-se que essa legitimação da dimensão terapêutica, dentro de certo formato, foi acompanhada da aproximação de instituições espíritas com o Estado pela via da assistência social, o que já ocorria, em grau bem maior, na relação com a Igreja Católica e correspondia, mesmo sem alcançar a mesma legitimidade, ao exercício da "colaboração" consagrada pela Constituição de 1934 e ratificada nas seguintes.

Embora a base legal contra a qual se conquistou a extensão do reconhecimento do estatuto de "religião" cobrisse, como se mencionou, os cultos mediúnicos em geral, o contraste entre o espiritismo e outras práticas é inegável. Os espíritas não apenas ficaram menos vulneráveis às incursões repressoras, como também exercitaram amplamente as prerrogativas civis concedidas às associações religiosas. Sabe-se que muitos terreiros de umbanda e candomblé, por outro lado, não possuem registro em cartório. Um comentarista, que é também militante, constata que "na cidade de São Paulo ainda hoje nenhum templo de candomblé tem assegurada a imunidade tributária, os ministros não conseguem obter inscrição no sistema de seguridade social e os cartórios se recusam a reconhecer a validade dos casamentos celebrados no candomblé" (Silva Jr. 2007:315). Mais do que isso: alguns dados e a memória dos adeptos registram que, em período recente (anos 1960 e 70), havia exigências de autorização administrativa ou registro policial para permitir o funcionamento de terreiros. Todas essas características evidenciam a dificuldade que os cultos de possessão de referência africana encontram para se adequar ou serem reconhecidos em seu estatuto de "religião". E se é possível notar investimentos que buscam produzir essa adequação e reconhecimento, também se pode constatar a construção de uma outra via de presença da religião no espaço público. 
Chamarei essa via de "diferencialista", por oposição a que acompanhamos anteriormente, que denomino "generalista" - na falta de termos mais precisos e sem fazer sobre eles qualquer juízo de valor. Sua articulação permite, por exemplo, que os "cultos afro-brasileiros" componham uma dimensão da cultura pública, como ocorre mais claramente na Bahia, onde o candomblé faz parte de uma "baianidade" oficialmente promovida (Sansi 2003). Mas gostaria de explorar aspectos que remetem ainda à própria existência dos terreiros e das condições para suas manifestações. Essa é uma questão que preocupava Nina Rodrigues, que, na passagem do século XIX para o XX, compôs uma representação dos terreiros de candomblé capaz de conciliar aspectos, em princípio, contraditórios. Refiro-me ao fato de que o médico radicado na Bahia denunciava, com base na medicina acadêmica, as práticas de cura africanas e, ao mesmo tempo, reclamava para os praticantes de "feitiços" a proteção que a Constituição republicana devia às "religiões". Outro momento em que reivindicação semelhante é articulada ocorre durante os dois Congressos Afro-Brasileiros, realizados no Nordeste na década de 1930. Como mostra Dantas (1988), houve também a preocupação em caracterizar os cultos afro-brasileiros como "religiões". Lembremos que esses congressos contaram com a participação de figuras importantes do cenário intelectual brasileiro. Suas posições revelam a referência comum ocupada pela categoria "religião" na luta por legitimação social.

No quadro do Congresso Afro-Brasileiro realizado em Salvador, no ano de 1937, um memorial, elaborado por Édison Carneiro, foi dirigido ao governador baiano com o fim de apoiar a reivindicação de "liberdade religiosa" para as "seitas africanas". Os termos utilizados são significativos, por evocarem a posição de outros intelectuais e noções ancoradas na Constituição então vigente:

Cada povo tem a sua religião, e sua maneira especial de adorar a Deus - e é o candomblé a organização religiosa dos Negros escravos e dos Homens de Cor da Bahia, descendentes dos Negros escravos, que lhes deixaram, como herança intelectual, as várias seitas africanas em que se subdividem as formas religiosas trazidas da África (...). Como têm provado, suficientemente, os mais argutos observadores, notadamente Nina Rodrigues e Arthur Ramos, e os Congressos Afro-Brasileiros já realizados (...), nada há, dentro das seitas africanas, que atente contra a moral ou contra a ordem pública (art. 113 da Constituição Federal). Ao contrário, tanto Nina Rodrigues e Arthur Ramos quanto os intelectuais que colaboraram nos citados Congressos, todos, sem exceção, têm reclamado a liberdade religiosa dos Negros como uma das condiçóes essenciais para o estabelecimento da justiça entre os homens. (apud Dantas 1988:190). 
O que pretendo destacar é que havia, em posições como essas, um argumento de viés culturalista. Nina Rodrigues poderia ilustrar isso, como sugere o manifesto acima, mas seu compromisso com o biologicismo prejudicaria a demonstração. Vale mencionar, no entanto, que ele se referia a um "sentimento religioso", contra o qual a polícia de nada adiantaria, para traduzir o "fetichismo animista" a que associava os "feitiços africanos". Passo então às visões de Arthur Ramos, um intelectual em sintonia com os investimentos dos Congressos AfroBrasileiros e que está vinculado a argumentos propriamente culturalistas (Corrêa 1998). Detenho-me em um texto apresentado em um congresso médico de 1931, no qual Ramos propõe uma distinção entre "charlatanismo" e "curandeirismo" (Ramos 1931). O "charlatão" é sempre um médico que transgride seu código de classe; já o "curandeiro" é o indivíduo que se dedica a práticas de cura informado por "concepções mágicas". Não se pode confundi-los, conferindo a ambos as mesmas medidas de ataque. No caso do "curandeiro", o que se tinha, segundo Ramos, era um problema de "mentalidade" baseada em uma psicologia e uma cultura diferenciais. Embora as visões de Ramos estivessem orientadas por uma perspectiva de "superação", elas recorrem a argumentos que podem, em outros discursos, adquirir um sentido positivo para suportar a existência e a presença de certas religiões. $O$ que os caracteriza é exatamente a idéia de que essas religiões se constituem, no diálogo com outras, de modo diferencial. ${ }^{8}$

Para demonstrar minha proposição, enfoco rapidamente duas situações recentes. A primeira ocorre no final dos anos 1980 em São Paulo e trata do tombamento de um terreiro de candomblé pelo organismo estadual voltado para a proteção do patrimônio cultural. Valho-me do comentário realizado por Silva (1995:183-196), que ressalta a novidade do procedimento e as tensões em meio às quais se efetivou. Na prática, o pedido do tombamento foi a solução encaminhada para enfrentar um impasse que se colocava no plano dos direitos de propriedade do imóvel em que se localizava o terreiro. $O$ falecimento do paide-santo que fundou o terreiro provocou uma disputa civil pela herança; o tombamento garantiu que a herdeira cuja autoridade religiosa se consolidara na sucessão ficasse também com a posse do imóvel. Assim, o procedimento efetivado representou a exploração de uma via jurídica alternativa para resolver o problema da transferência de propriedade, problema que está diretamente ligado às formas de autoridade nesse universo religioso. Tão importante quanto isso é notar que o tombamento considerou o terreiro como "espaço cultural" e, para isso, envolveu uma fundamentação antropológica para a sua efetivação. Foi, portanto, a título de "cultura" que esse reconhecimento ocorreu, aceitando-se que a religião pudesse ser assim concebida e considerada. ${ }^{9}$

A outra situação ocorre nesta década e envolve controvérsia jurídica, no estado do Rio Grande do Sul, sobre o abate de animais em cultos afro-brasileiros ${ }^{10}$. Em 2003, tornou-se lei estadual um código de proteção aos animais cujo projeto 
legislativo, em sua primeira versão, trazia proibição a práticas e eventos, inclusive "cerimônia religiosa, feitiço", que implicassem em maus tratos ou morte. $\mathrm{Na}$ versão definitiva, não constavam essas expressões do texto, mas houve preocupação de que a nova redação ainda permitisse a interdição de sacrifícios de animais nos cultos afros. A lei vedava que se ofendesse ou agredisse fisicamente um animal e exigia que se desse "morte rápida e indolor a todo animal cujo extermínio seja necessário para o consumo”. Houve, em seguida à aprovação da lei, mobilização entre lideranças do universo religioso e dos movimentos negros, que deu ensejo à proposição de um texto que eliminasse a possibilidade de interpretação lesiva aos cultos afro. A mobilização teve êxito, conduzindo à nova lei, que acrescentava a seguinte disposição às provisões já citadas: "Não se enquadra nessa vedação o livre exercício dos cultos e liturgias das religiões de matriz africana”. Depois disso, a Procuradoria buscou, atendendo a pedido de entidades de defesa dos animais, derrubar a nova lei, mas o Tribunal de Justiça indeferiu a solicitação. A decisão final ocorreu em 2006, culminando um debate que se desenrolou inclusive na imprensa local.

O que me importa reter desse debate é a argumentação sustentada pelos defensores da legitimidade dos sacrifícios animais. Ela explora fundamentações de duas ordens. Em uma delas, a prática de abate dos animais em terreiros é defendida por sua aproximação com outras práticas de abate que não teriam nada de rituais. Como garantir que todo animal seja abatido nas condições sanitárias ideais sem cair em precauções absurdas ou medidas discriminatórias? ${ }^{11}$ Um ponto importante era a questão da "crueldade", levantada mesmo pelo governador como ressalva para aprovar a mudança no texto original da lei. Novamente, o argumento dos defensores dos sacrifícios animais apelava para a impossibilidade de uma aplicação literal, pois toda forma de abate para consumo humano implica em algum grau de crueldade. Em suma, até aqui o que temos são modos de legitimação que inserem o sacrifício religioso em condições mais gerais que cercam o abate animal. Mas em outra linha de argumentação, é exatamente o caráter "religioso" que legitima o abate. "Religioso", nesse caso, traduz um aspecto de toda uma "tradição" e opera como um signo distintivo. Significativamente, embora o argumento considere que outras religiões envolvam sacrifícios animais, o texto legal menciona apenas "as religiões de matriz africana".

Esse segundo vetor cultiva, portanto, as prerrogativas da exceção. Ele nos permite ter mais clareza sobre a distinção entre os argumentos generalista e diferencialista na base dos modos de presença e legitimação. No primeiro caso, a noção de religião é acionada e construída de tal forma que, mesmo quando sua referência é bem específica (como vimos na discussão sobre liberdade religiosa), pressupõe-se que configura um gênero que pode ser preenchido por muitas espécies. No segundo caso, a noção de religião é diretamente acionada e construída por referência a condições específicas, sem constituir uma regra 
pretensamente geral; por isso, a extensão para outras demandas nunca é automática. Esse segundo argumento se desenvolveu mais claramente a propósito das "religiões afro-brasileiras" porque foi sobretudo em torno delas que se articulou a posição que as vinculava fortemente a uma "mentalidade", a uma população e a uma tradição específicas ${ }^{12}$. Assim, elaborou-se uma base diferencialista para sustentar a presença dessas religiões no espaço público brasileiro, que é distinta da base que se configurou para permitir a presença do catolicismo e do espiritismo no mesmo espaço. Apresso-me em destacar: veremos mais adiante que o argumento diferencialista não funciona apenas para o modo de inserção e presença das religiões afro-brasileiras, nem se fundamenta necessariamente em argumentos culturalistas.

Mas, como a noção de "cultura" acaba de aparecer de modo relevante, é preciso antes notar a polissemia que a acompanha. Esta fica evidente na sua associação com a idéia de "patrimônio", mencionada explicitamente na primeira situação (tombamento de um terreiro) e passível de ser acionada na outra (a religião como "patrimônio" de um grupo específico). Pois há pelo menos dois sentidos em jogo. "Cultura como patrimônio" pode remeter a uma concepção cumulativa, que envolve portanto uma gradação, supondo um ponto a partir do qual o acúmulo passa a merecer dignificação e valoração. Ela é seletiva no sentido de que pode ser utilizada para distinguir certos objetos, invenções, eventos, monumentos, etc. em relação a outros. É isso o que faz, por exemplo, um tombamento. Por outro lado, "cultura como patrimônio" pode também ser tomada dentro de uma concepção pluralista, que opera, por assim dizer, inversamente, ou seja, para "horizontalizar" o reconhecimento. Nessa acepção, qualquer "grupo" possui "sua cultura", singular, e valorizá-la enquanto tal é uma forma de promovê-la (por exemplo, eximindo-a legalmente de uma norma geral). Ainda há mais: a distinção entre concepção cumulativa e a pluralista pode ser atravessada ou estar subsumida àquela entre argumentos diferencialista e generalista. Aqui, o significante é novamente polissêmico: pois "cultura" pode ter conotações particularistas (relativas a um grupo específico), mas também ser considerada como dimensão constitutiva do social ou do humano (exemplo: quando um templo católico de "valor histórico" é tombado pelo Ministério da Cultura). Esses vários sentidos e concepções permitem, portanto, passagens entre si. Os evangélicos, sobretudo, é que vão demonstrar isso.

$$
* * *
$$

É difícil sobrestimar o impacto da inserção dos evangélicos na sociedade brasileira das últimas décadas. Seu crescimento numérico talvez seja um aspecto menor. Por conta de sua ação, o campo da política, definida estritamente, é incapaz de ignorar atualmente o fator "religioso". A indicação e o apoio a 
candidaturas legislativas por parte de igrejas, a mobilização para a defesa de interesses supradenominacionais (caso das "frentes parlamentares"), a identificação com titulares de postos do Poder Executivo - são todos movimentos, ocorridos com sucessos e revezes, protagonizados pelos evangélicos que têm se dedicado ao uso da identidade religiosa como atributo eleitoral (Machado 2008; Oro 2003). Paralela ou conjuntamente, observamos a presença de agentes referidos como evangélicos na execução de políticas públicas e em parcerias com agências governamentais (Machado 2003). Tal presença, ao mesmo tempo em que se fundamenta na legitimidade de "colaboração" entre Estado e igrejas, agora aproveitada por mais um segmento do campo religioso (tradicionalmente, católicos e espíritas cumpriam esse papel), beneficiase de uma abertura mais recente para a participação da sociedade civil nas políticas públicas e de uma valorização generalizada da atuação em rede no enfrentamento da questão social (Burity 2006).

Em outro plano, a prosperidade, ainda que seja um termo específico a certas de suas vertentes, serve para apontar outras provocações lançadas pelos evangélicos. Ela identifica, primeiro, a prática teologicamente fundada que se traduz no pedido de dinheiro durante os cultos. Na leitura de Montero (2006), trata-se de uma inversão do princípio instituído, prevalecente no campo religioso e socialmente legitimado, da caridade: ao invés de doar, a religião pede. Além disso, a prosperidade é o fulcro de uma mensagem, mais amplamente difundida e atrelada aos signos do mundo dos negócios, como ressalta Birman (2003), que rompe os vínculos secularmente estabelecidos entre pobreza, religião e tradicionalidade. Tal mensagem se articula em práticas permeadas por milagres, testemunhos e exorcismos, constituídas em diálogo próximo com as referências populares e, ao mesmo tempo, exercitadas em espetáculos midiatizados que são o correspondente virtual da ocupação de espaços públicos bem concretos por multidões religiosamente mobilizadas (além de Birman, ver Corten 1996 e Mafra 2002). Temos aí, novamente na leitura de Montero (2006), uma segunda inversão, pela qual magia e religião deixam de ser opostas e passam a se conciliar.

Concordo com tudo isso. Apenas não vejo como essas inovações ou provocações se projetariam no plano que viemos acompanhando ao longo deste texto. É surpreendente que tamanha movimentação nas relações entre religião e sociedade não consiga gerar transformações correlatas nos arranjos que regulam a inserção da religião no espaço público ${ }^{13}$. Retomo alguns dos pontos ressaltados acima para constatar que cada um deles sugere ou uma inadequação (que corresponde à suspeita generalizada acerca da legitimidade dos evangélicos) ou uma adequação (que corresponde à defesa que certos segmentos articulam diante das acusações), mas jamais uma transformação. Tomemos, por exemplo, a política: às acusações de teocratismo, de intromissão do religioso, os evangélicos retrucam com a obediência às regras do jogo democrático. Quando são reprovados pela prática de uma espécie de estelionato espiritual, replicam com a 
demonstração da liberdade que acompanha as doações dos fiéis. Quando são criticados pela sua intolerância, objetam que estão apenas manifestando a sua opinião. Não se trata apenas de registrar esse diálogo dissonante, mas de constatar que não temos modificações legais em resposta a esses pontos de conflito.

Talvez o que estejamos vendo neste momento, como já argumentei (Giumbelli 2002), é um desafio às formas tácitas que organizam a definição do "religioso" no Brasil. É possível que esse desafio provoque mudanças importantes nos dispositivos que configuram aquela definição. Ao mesmo tempo, penso ser interessante insistir em uma espécie de investigação indireta, que vai buscar por respostas não nos mecanismos que se dirigem imediatamente ao religioso, mas naqueles que, ao regular outros domínios, acabam tendo interferências nele. Vasculhemos portanto alguns dos instrumentos legais ou esferas de regulação com que já nos deparamos. Foi assim que encontrei pontos nos quais a presença dos evangélicos já envolve impacto significativo no período recente. Refiro-me ao Código Civil, que teve nova versão em vigor desde 2003, e a uma proposição de mudança legislativa que se coloca no plano das políticas públicas voltadas para a área da "cultura". Juntas, essas ocorrências sugerem, por formas inusitadas, redimensionamentos nos modos generalistas e diferencialistas de legitimação do religioso.

Embora ainda pouco analisada, uma mobilização em 2003 percorreu sobretudo o universo evangélico envolvendo um protesto contra o novo Código Civil ${ }^{14}$. Alegou-se que este criava a possibilidade de um controle das igrejas por parte do Estado, atentatório à liberdade religiosa. Isso ocorreria, continuava o protesto, porque as organizações religiosas passaram a ser tratadas como qualquer outro tipo de "associação", uma das modalidades de pessoa jurídica de direito privado previstas no Código. O texto legal estipula algumas atribuições do poder público sobre a vida das associações, reforça os direitos de membros em relação aos dirigentes, reitera a proibição de lucro, exige a manutenção dos registros contábeis e a necessidade de declaração de renda. Não tenho condições de me pronunciar sobre se isso representa um maior controle em relação aos dispositivos que já existiam no ordenamento legal brasileiro dirigido ao universo das entidades sem fins lucrativos. Mas o que pode ser problematizado é o protesto levantado pelos evangélicos preocupados com as condições de funcionamento de suas e de outras igrejas: estaria havendo um desrespeito ao estatuto jurídico próprio das organizações religiosas.

O protesto, nesses termos, é surpreendente. Pois não vimos que o Código Civil anterior não criou diferenciações entre as associações religiosas e demais tipos de associação obedecendo exatamente ao argumento de que nenhuma restrição específica deveria pesar sobre as primeiras? Ocorre que, por força de outros dispositivos ou mesmo da prática administrativa ou da jurisprudência judiciária, as igrejas foram sim, em certos aspectos, tratadas diferencialmente. 
O item mais evidente é o da imunidade tributária, que adquiriu estatuto constitucional desde 1946, mas já era aplicada anteriormente por conta de legislações mais específicas. Outros itens tomam novamente como referência a Igreja Católica e envolviam: a permissão para formas hierarquizadas de organização de coletivos religiosos, o que incluía o reconhecimento de personalidade jurídica a entidades, como dioceses e paróquias, cuja existência era regida por leis canônicas; a imprescritibilidade e inalienabilidade dos bens religiosos, sobretudo os templos, o que significava que os coletivos religiosos não eram restringidos quanto ao recebimento de bens e eram protegidos quando ao desembaraço deles (para detalhes, ver Giumbelli 2002).

Ou seja, de um certo modo, fazia sentido a referência dos protestantes ao estatuto legal diferenciado dos coletivos religiosos; daí as precauções contra a falta de distinção no novo Código Civil. Como solução, chegou-se a uma modificação no texto da lei que foi rapidamente definida e acordada, ${ }^{15}$ e que resultou na seguinte estipulação: "São livres a criação, a organização, a estruturação interna e o funcionamento das organizações religiosas, sendo vedado ao poder público negar-lhes reconhecimento ou registro dos atos constitutivos e necessários ao seu funcionamento" (Art. 44, $\left.\S 1^{\mathrm{o}}\right)^{16}$. Mas a principal inovação consistiu na criação de outras duas figuras como modalidades de pessoas jurídicas de direito privado, entre elas a das "organizações religiosas". As conseqüências, a longo prazo, dessa modificação não são evidentes e podem servir de base para maiores controles; de imediato, contudo, o que ela faz é desatrelar as "organizações religiosas" do conjunto de mecanismos regulatórios previstos no mesmo texto para as "associações" sem, ao mesmo tempo, providenciar automaticamente outros que lhes sejam cabíveis. Em suma, pretendendo "deixar como era", o que se conseguiu foi introduzir a especificação dos coletivos religiosos dentro da principal lei civil brasileira. Por ora e por conta da redefinição do Código Civil, as igrejas figuram como exceções à norma geral. ${ }^{17}$

A outra situação que enfocarei com envolvimento dos evangélicos é o projeto de lei proposto por Marcelo Crivella, apresentado no Senado em 2005. Ele altera uma lei de 1991, que institui o Programa Nacional de Apoio à Cultura (PRONAC), mais conhecido como Lei Rouanet, que permite que empresas invistam em projetos culturais parte do que devem como imposto de renda. A proposta de Crivella, se aprovada, possibilitaria que, além de museus, bibliotecas e arquivos, também "templos" fossem beneficiados com recursos no âmbito do PRONAC. Houve uma forte reação no meio artístico, sobretudo depois que o projeto foi aprovado pela comissão temática encarregada de apreciálo no Senado, em 2007. Essas reações focaram na denúncia da perversão da finalidade de recursos escassos, e também no caráter auto-referido da proposição. Tentando remediar o segundo aspecto, o texto aprovado na Comissão de Educação destaca a abrangência acatando a emenda de outro senador: "templos de 
qualquer natureza ou credo religioso”. Espera-se agora que ocorra a discussão em plenário. $^{18}$

Considerando essa controvérsia, gostaria de ressaltar alguns aspectos das justificativas apresentadas por Marcelo Crivella. No texto que acompanha a proposta original, destaca-se o papel civilizatório da religião na edificação da cultura nacional. O seguinte trecho vale ser transcrito: "Ora, nada expressa melhor a formação dessa cultura que o caldeamento das diversas religiões, seitas, cultos e seus sincretismos, que, durante séculos, moldaram o processo civilizatório nacional e, ainda mais, por tempos que virão, continuarão a ser o barro e o fermento que construirão os nossos pósteros". Ressaltando a contribuição das "crenças, cultos ou religiões" para a solidariedade social, para a "consciência cívica e cultural", reivindica que sejam reconhecidos como "parcela indissolúvel do "patrimônio cultural brasileiro"'19. Já em pronunciamentos ocorridos em meio à polêmica levantada por sua proposta, Crivella, mesmo mantendo referência ao "patrimônio histórico e cultural brasileiro", restringiu a canalização dos recursos apenas para "restauração e conservação de templos históricos", ou seja, os "já tombados". 20

○ jogo de argumentos e formulações merece um comentário. A primeira versão justificativa apelava para o papel civilizatório da religião, associando a noção de patrimônio à concepção cumulativa de cultura. Ao mesmo tempo, lançava mão de uma formulação abrangente sobre o seu objeto. Abrangente em seus termos - "religiões, seitas, cultos e seus sincretismos" - e abrangente em seus fins - permitir que os "templos" se acrescentassem aos beneficiários de recursos públicos. Se considerarmos que a Lei Rouanet vem sendo utilizada para gerar recursos aplicados em projetos pautados por uma concepção mais estrita de "cultura", compreende-se a reação que se levantou no meio artístico. Crivella, em sua segunda versão justificativa, de certo modo, leva isso em conta, pois recorre a uma restrição calcada na expressão "templos históricos". Assim, apenas certas entidades religiosas seriam elegíveis, ainda que dentro da mesma concepção cumulativa de cultura, compartilhada, aliás, pelos usuários correntes do PRONAC. Ao restringir os benefícios para monumentos históricos, Crivella aceita a subordinação do "religioso" ao "cultural". Mesmo assim, sua proposta reitera e engrossa a existência de um modo de presença do religioso no espaço público que passa pela cultura e que pode se adequar a um argumento generalista.

Note-se que a segunda versão não ganhou correspondência com o texto do projeto atualmente em apreciação. A única modificação ocorrida propiciaria, como vimos, que "qualquer credo" fosse contemplado. Isso permitiria, por exemplo, que templos afro-brasileiros pudessem ser reconhecidos como beneficiários. Ao mesmo tempo, abriria a possibilidade de uma acepção pluralista para a definição de cultura. De todo modo, destaquemos que a novidade é exatamente a entrada 
dos evangélicos como beneficiários de recursos concedidos publicamente através de políticas culturais. Consideremos agora novamente a segunda versão justificativa de Crivella. Nela são nominalmente citadas, como exemplos de "igrejas históricas", "múltiplas igrejas católicas, presbiterianas, metodistas, congregacionais e batistas". Crivella não menciona terreiros afro-brasileiros e parece ter desistido da formulação abrangente utilizada na primeira versão justificativa. Na sua última formulação, além de algumas igrejas protestantes, é a Igreja Católica que merece distinção. Curiosamente, essa deferência de um evangélico aos católicos tem um correlato na revisão do Código Civil. Pois a mobilização de lideranças e entidades evangélicas, acima analisada, recebeu a adesão da CNBB, o que foi fundamental para o seu sucesso (cf. Mariano 2006).

Isso nos leva a uma outra discussão, ocorrida em 2007. Por ocasião da visita papal ao Brasil, foi divulgada a existência de uma negociação entre o Vaticano e o governo local, por iniciativa do primeiro. $O$ foco dessa negociação é uma espécie de acordo que definiria o estatuto jurídico de uma série de questões atreladas à atuação de agentes católicos e à presença do catolicismo no espaço público. Questões referidas ao tema da sexualidade foram levantadas na repercussão das negociações, sobretudo por conta dos debates correntes sobre direitos sexuais e reprodutivos e o estatuto legal de certas pesquisas científicas, mas não faziam parte do documento propositivo. Neste, o Vaticano manifestou interesse em garantir o ensino religioso obrigatório em escolas públicas e a entrada de missionários em áreas indígenas. Outros assuntos têm relação direta com as duas controvérsias recentes que acompanhamos. Pois o documento apresenta reivindicações que incidem sobre o reconhecimento de sua forma de organização e sobre matéria fiscal (confirmação de imunidade tributária), e ainda sobre a preservação do patrimônio materializado em seus templos históricos. ${ }^{21}$

A idéia de um acordo entre Vaticano e o Estado brasileiro parece esdrúxula ${ }^{22}$. Do ponto de vista da Igreja Católica, no entanto, faz algum sentido. No Brasil, a hegemonia católica no espaço público se construiu recorrendo a um arranjo basicamente liberal, que dificultou a explicitação de um reconhecimento privilegiado. Compare-se isso com a situação de alguns países europeus nos quais as bases para esse reconhecimento são mais sólidas (concordatas e outros "acordos"), o que propicia, em alguns casos e em conjunturas recentes (Espanha, por exemplo), ameaças mais claras para o arranjo estabelecido. $O$ sonho do Vaticano para o Brasil é o de um acordo que garanta solidez sem suscitar as ameaças. Mas existem também razões de ordem interna. O novo Código Civil produziu um vácuo jurídico em relação às "organizações religiosas". Um "acordo" poderia preenchê-lo. Além disso, o campo da relação entre "cultura" e "religião" é atravessado por movimentos cujos resultados, como se viu no caso do projeto Crivella, são incertos. Novamente, um "acordo" garantiria a proteção ao "patrimônio histórico católico", de grandes proporções materiais e simbólicas. 
De todo modo, não deixa de ser inusitado o surgimento de uma via excepcionalista como base para a normatividade da religião majoritária no Brasil.

Creio que estivemos sempre às voltas, nos temas e situações que preencheram este texto, com a questão das fronteiras. Primeiro, aquelas entre Estado e religião, que não se configuram necessariamente como muro que impede as relações. O que procurei destacar foi a constituição de modos de presença que permitem, legitimamente, o reconhecimento do religioso no espaço público, modos que dialogam, mesmo que não se definam apenas por ele, com o princípio da laicidade. Segundo, tratamos das fronteiras entre forças e segmentos do campo religioso. Novamente, o foco nos modos de presença demonstra a validade dessas fronteiras (na seqüência catolicismo-espiritismo-cultos afro-religião evangélica), mas ao mesmo tempo revela a existência de relações e cruzamentos inusitados (pelos quais evangélicos beneficiam católicos, e vice-versa). Vale ressaltar que os argumentos apresentados aqui se valem de empreendimentos investigativos dispersos e apostam na aproximação entre situações aparentemente desconexas. Ou seja: trata-se de temas que merecem maior pesquisa empírica e mais discussão conceitual e analítica.

Mas é possível, desde já, levantar algumas questões a propósito de dois temas. O primeiro relaciona-se com as "políticas de reconhecimento". O tema é vasto, por conta das contribuições ilustres que tem atraído nas últimas décadas, vindas sobretudo da filosofia política, mas também pela multiplicidade de situações empíricas que vêm entrando em sua órbita recentemente, muitas delas acompanhadas por estudos antropológicos. Minha intervenção é singela e referese apenas a um texto, que toca diretamente na questão do "reconhecimento de grupos religiosos" (Modood 2000). Nele, o autor baseia-se na realidade britânica, com o foco voltado para a situação de minorias étnicas, mas dirigindo-se a debates mais amplos, acerca de "cidadania multicultural" e "nacionalidade hifenada”. Sua proposta é resumida nos seguintes termos: “(...) existe uma incompatibilidade teórica entre multiculturalismo e secularismo radical. Isso significa que, em uma sociedade na qual algumas das minorias desfavorecidas e marginalizadas são religiosas, uma política pública multicultural demandará o reconhecimento público de minorias religiosas" (:194). Ele aposta assim em "compromissos institucionais" entre Estado e religiões, apontando para um "secularismo moderado" que possa responder às demandas fundamentadas no multiculturalismo.

Modood sabe que está sendo ousado, pois ele mesmo aponta que "muitos teóricos da diferença e do multiculturalismo demonstram muito pouca abertura para grupos religiosos” (:187). Em apoio à sua proposta, ele esboça uma análise 
que constata, por toda a Europa ocidental, "pontos de vínculo, simbólicos, institucionais, administrativos, fiscais, entre Estados e aspectos do cristianismo" (:189). Mas essa análise mantém um viés monumental, com atenção reduzida para dispositivos heteróclitos de reconhecimento. Talvez por isso Modood exclua a França de suas constatações. De minha parte, prefiro encarar a laicidade francesa como um regime de reconhecimento do religioso (Giumbelli 2002). Para demonstrá-lo, procuro tratar das formas históricas pelas quais as religiões e o religioso tornam-se objeto de elaboração estatal. No quadro contemporâneo, duas situações são particularmente reveladoras. Primeiro, a controvérsia sobre as "seitas", pois se lhes nega os atributos que se reconhecem às "religiões". Segundo, o tratamento do islã, que oscila entre críticas que lamentam sua situação na França e intervenções que buscam corrigir o que se percebe ora como falta, ora como excesso. É curioso que Modood, em seu texto, está particularmente preocupado com os muçulmanos na Grã-Bretanha e é pensando neles que insinua "formas especiais de representação" para grupos religiosos. Ora, na França esse é um ponto recorrente das discussões sobre o islã que contam com o envolvimento estatal.

A referência às minorias étnicas como base para "políticas de reconhecimento" é outro ponto sujeito a debate. Pois ele não estava presente nas formulações clássicas acerca da "liberdade religiosa". Locke (1973), por exemplo, não estava pensando em grupos étnicos quando escreveu sua Carta acerca da Tolerância. Nas suas visões, os grupos religiosos são formações voluntárias, que reúnem os que concordam com as mesmas proposições de fé. É claro que essa concepção traduz um entendimento bastante particular do que seja uma "igreja"; mas também particular é a etnicização da religião, e o que há de comum a ambas é o fato de se relacionarem com formas históricas e concretas. Torna-se então importante referir a discussão sobre "políticas de reconhecimento" a tais formas, sempre plurais. Em se tratando do Brasil, temos uma situação interessante, pois as "minorias" religiosas não se comportam da maneira esperada (Giumbelli 2006). Para ficar apenas no caso dos evangélicos: suas reivindicações recentes por "liberdade religiosa", essas sim típicas de uma minoria, vêm seguidas de ações e estilos que insinuam um projeto de maioria. Parece-me que as formas de presença tematizadas neste artigo a propósito dos evangélicos ratificam essa dualidade e seus dilemas.

O segundo tema a merecer provocações é o das definições de "espaço público”. Assim como não pautei minha discussão sobre modos de presença por uma perspectiva normativa (e aqui está outra diferença em relação a Modood), não o faço com respeito à noção de "espaço público". Sei bem que tais definições existem, tanto em versões liberais, quanto em versões habermasianas - para citar apenas duas referências entre outras do debate recente na filosofia política. Prefiro, no entanto, adotar a expressão em sentido o mais lato possível, 
percorrendo empiricamente as situações variadas que podem encarná-la. Isso permite apreender as formas históricas com que se constitui - ou se pressupõe - certo espaço de interação pública, sem desconsiderar a existência de assimetrias entre os elementos que o povoam e sem esquecer que sua produção envolve dimensões que podemos chamar de simbólicas. Asad é novamente inspirador:

Os limites à livre expressão não são apenas aqueles impostos por leis e convenções - ou seja, por um poder externo. Eles são também intrínsecos ao tempo e espaço necessários à construção e demonstração de um argumento particular, à expressão (ou compreensão) de uma experiência particular - e mais amplamente, à formação de sujeitos participantes particulares. (Asad 1999:18081).

Vê-se que não se pode problematizar o espaço público sem atentar para as condições dos atores que se localizam na sociedade; a noção, no entanto, coloca permanentemente em jogo a constituição e o papel do Estado. Estamos, assim, ainda às voltas com o argumento da secularização e suas expectativas para a relação entre religião e espaço público.

\section{Referências Bibliográficas}

ASAD, Talal. (1993), Genealogies of religion. Discipline and Reasons of Power in Christianity and Islam. Baltimore: The Johns Hopkins University Press.

. (1999), "Religion, Nation-State, Secularism". In: P. Van der Veer e H. Lehmann (orgs.). Nation and Religion. Princeton: Princeton University Press.

. (2003), Formations of the Secular: Christianity, Islam, Modernity. Stanford: Stanford University Press.

. (2006a), "Appendix: the trouble of thinking" (interview by D. Scott). In: D. Scott

e C. Hirschkind. Powers of the Secular Modern. Talal Asad and his interlocutors. Stanford: Stanford University Press.

. (2006b), "Trying to understand French Secularism". In: H. de Vries e L. Sullivan (orgs.). Political Theologies - public religions in a post-secular world. Nova Iorque: Fordham University Press.

BIRMAN, Patrícia. (2003), "Imagens religiosas e projetos para o futuro". In: P. Birman (org.). Religião e Espaço Público. São Paulo: Attar.

BURITY, Joanildo. (1997), "Entre o reino de Deus e a autoridade civil: pentecostais, cultura e política". In: Identidade política no campo religioso. Recife: Editora da UFPE. (2006), Redes, parcerias e participação religiosa nas políticas sociais no Brasil. Recife: Fundação Joaquim Nabuco, Ed. Massangana.

CANTARINO, Carolina. (2005), "Quando os deuses se materializam". Reportagem para o "Dossiê Brasil Afro-Descendente". Patrimônio - Revista Eletrônica do IPHAN, 1 (disponível em http:// www.revista.iphan.gov.br/materia.php?id $=44$, consultado em 01.08.2008)

CORRÊA, Mariza. (1998), As ilusões da liberdade: a Escola Nina Rodrigues e a antropologia no Brasil. 
Bragança Paulista: EDUSF.

CORTEN, André. (1996), Os pobres e o Espírito Santo. O pentecostalismo no Brasil. Petrópolis: Vozes.

DANTAS, Beatriz Góis. (1988), Vovô nagô e papai branco - usos e abusos da África no Brasil. Rio de Janeiro: Graal.

GIUMBELLI, Emerson. (1997), O cuidado dos mortos: uma história da condenação e legitimação do espiritismo. Rio de Janeiro: Arquivo Nacional.

. (2002), O Fim da Religião: Dilemas da Liberdade Religiosa no Brasil e na França. São Paulo: Attar/PRONEX.

. (2003), "Religião e espaço público no caso do Cristo no júri, Rio de Janeiro, 1891". Acervo (Revista do Arquivo Nacional), 16 (2): 19-42.

. (2006), "Minorias religiosas". In: F. Teixeira e R. Menezes (orgs.). As religiões no Brasil - continuidades e rupturas. Petrópolis: Vozes.

LOCKE, John. (1973), "Carta acerca da tolerância". In: Os Pensadores. São Paulo: Abril Cultural. MACHADO, Maria das Dores Campos. (2003), "Igreja Universal: uma organização providência". In:

A. P. Oro, A. Corten, J. P. Dozon (orgs.). Igreja Universal do Reino de Deus - os novos conquistadores da fé. São Paulo: Paulinas.

. (2008), "A atuação dos evangélicos na política institucional e a ameaça às liberdades laicas no Brasil”. In: R.A. Lorea (org.). Em defesa das liberdades laicas. Porto Alegre: Livraria do Advogado.

MAFRA, Clara. (2002), Na Posse da Palavra: religião, conversão e liberdade pessoal em dois contextos nacionais. Lisboa: Imprensa de Ciências Sociais.

MAGGIE, Yvonne. (1992), Medo do feitiço: relações entre magia e poder no Brasil. Rio de Janeiro: Arquivo Nacional.

MARIANO, Ricardo. (2006), "A reação dos evangélicos ao novo Código Civil". Civitas - Revista de Ciências Sociais, 6 (2). http://revistaseletronicas.pucrs.br/ojs/index.php/civitas/article/viewFile/57/ 57 (acesso em 18.04.08)

MODOOD, Tariq. (2000), "Anti-essentialism, multiculturalism, and the 'recognition' of religious groups". In: W. Kymlicka, W. Norman (orgs.). Citizenship in Diverse Societies. Nova Iorque: Oxford University Press.

MONTERO, Paula. (2006), "Religião, pluralismo e esfera pública no Brasil". Novos Estudos CEBRAP, n. 74: 47-65.

ORO, Ari Pedro. (2003), "Igreja Universal: um poder político". In: A. P. Oro, A. Corten, J. P. Dozon (orgs.). Igreja Universal do Reino de Deus - os novos conquistadores da fé. São Paulo: Paulinas. . (2005), "O sacrifício de animais nas religióes afro-brasileiras: análise de uma polêmica recente no Rio Grande do Sul". Religião e Sociedade, 25 (2): 11-31.

RAMOS, Arthur. (1931), "O problema psicológico do curandeirismo". Brasil-Médico, 42: 39-49.

SANSI, Roger. (2003), "De imagens religiosas a ícones culturais: reflexões sobre as transformações históricas de algumas festas públicas na Bahia". In: P. Birman (org.). Religião e Espaço Público. São Paulo: Attar.

SILVA, Vagner Gonçalves da. (1995), Orixás da Metrópole. Petrópolis: Vozes.

SILVA Jr., Hédio. (2007), "Notas sobre sistema jurídico e intolerância religiosa no Brasil". In: V.G. Silva (org.). Intolerância religiosa - impactos do neopentecostalismo no campo religioso brasileiro. São Paulo: EDUSP.

SOUZA BANDEIRA, João. (1893), "Étude sur le régime légal des corporations de main-morte au Brésil". Bulletin de la Société de Legislation Comparée, 22: 569-595.

VAN der VEER, Peter. (2001), Imperial Encounters. Religion and Modernity in India and Britain. Princeton: Princeton University Press. 


\section{Notas}

1 Uma primeira versão deste texto foi apresentada na 26a. Reunião Brasileira de Antropologia, ocorrida em junho de 2008, em Porto Seguro, em mesa-redonda coordenada por Patrícia Birman, a quem agradeço o convite para essa participação. Patrícia Birman e Joanildo Burity têm sido interlocutores importantes em debates sobre o lugar do religioso na sociedade brasileira. Paula Montero, que esteve envolvida na mesma atividade na RBA, é autora de um texto (2006) com o qual este dialoga intensamente.

2 A idéia que insiste na necessidade de "provincializar" a Europa é forte no campo dos estudos póscoloniais. Para uma aplicação consistente dela, ver o trabalho de Van der Veer (2001).

3 Cf. texto da Constituição Federal de 1934: "Art. 17 - É vedado à União, aos Estados, ao Distrito Federal e aos Municípios: (...) II - estabelecer, subvencionar ou embaraçar o exercício de cultos religiosos; III - ter relação de aliança ou dependência com qualquer culto sem prejuízo de colaboração recíproca em prol do interesse coletivo".

4 Cf. texto da Constituição Federal de 1988: "Art. 19. É vedado à União, aos Estados, ao Distrito Federal e aos Municípios: I - estabelecer cultos religiosos ou igrejas, subvencioná-los, embaraçarlhes o funcionamento ou manter com eles ou seus representantes relações de dependência ou aliança, ressalvada, na forma da lei, a colaboração de interesse público".

5 Para uma discussão sobre essas aproximações, baseada em caso empírico, ver Giumbelli (2003).

6 Para um acompanhamento detalhado, em diálogo com a literatura pertinente, ver Giumbelli (2002).

7 Para análises sobre a repressão legal às religiões mediúnicas, ver Dantas (1988), Maggie (1992), Giumbelli (1997).

8 Sobre as posições de Arthur Ramos, ver, por exemplo, Dantas (1988) e Giumbelli (1997). Montero (2006), ao se referir a esses argumentos, utiliza-se de uma noção significativa: "religiões étnicas". A expressão, por si só, traz à baila uma discussão sobre a relação entre religião e povos indígenas. Ela incide sobre dois aspectos que se desdobrariam em muitos outros: a possibilidade de traduzir cosmologias e práticas indígenas como crenças e ritos religiosos, o que operaria uma sobreposição entre "cultura" e "religião"; a postura estatal, muito variável, acerca da atuação de grupos missionários em terras indígenas, com a possível incorporação de seus habitantes aos contingentes religiosos que identificam as missões. A especificidade dessas situações demanda um tratamento próprio, mas que não deveria se recusar ao diálogo com as questões levantadas neste texto.

9 Até 2005, o IPHAN (Instituto do Patrimônio Histórico e Artístico Nacional) havia formalizado o tombamento de seis terreiros de candomblé, o primeiro tendo ocorrido em 1984 (cf. Cantarino 2005). Outras iniciativas vêm ocorrendo em âmbito estadual e municipal. Destaque para a Bahia, cujo órgão competente estabeleceu o tombamento de sete terreiros entre 2004 e 2006. Em Salvador, uma providência da prefeitura protege terreiros como "patrimônio histórico e cultural de origem afro-brasileira".

${ }^{10}$ Para o debate, com seus argumentos e fases, ver Oro (2005) e Silva Jr. (2007).

${ }^{11}$ O argumento reedita uma alegação de Locke (1973) em sua Carta acerca da Tolerância no contexto da fundação do princípio da liberdade religiosa. Ver o comentário de Burity (1997) sobre esse texto e outras conexões com discussões no Brasil.

${ }^{12}$ Joga papel importante nessa construção a associação entre tais religiões e demandas identitárias relacionadas à negritude.

${ }^{13}$ Vale notar que até a década de 1950, as igrejas e adeptos protestantes, mesmo sofrendo discriminações em relação a católicos, não tiveram dificuldades legais para formalizarem a existência de suas instituições. Naquela década observam-se processos judiciais em resposta aos movimentos que propagandeavam a "cura divina"; mas, nesse caso, a defesa de práticas evangélicas podia seguir as pistas deixadas pelos espíritas. É apenas depois dos anos 80 que temos processos que mobilizam novas acusações (estelionato, intolerância, etc.).

${ }^{14}$ Mariano (2006) acompanhou o protesto e suas conquistas. Seu empreendimento analítico, contudo, 
não se refere ao que prefiro destacar adiante.

${ }^{15}$ Cf. Lei n⿳o 10.825, de 22.12.2003, disponível em http://www.planalto.gov.br/ccivil_03/leis/2003/ L10.825.htm\# art44.

${ }^{16} \mathrm{O}$ texto atualizado do Código Civil pode ser consultado em: http://www.planalto.gov.br/ccivil_03/ leis/2002/L10406.htm.

${ }^{17}$ Basta percorrer alguns registros na Internet para perceber que ocorre uma polêmica em torno do estatuto das "organizações religiosas", pois há quem considere que elas permanecem sujeitas a uma série de disposições do novo Código Civil. Mas insisto no fundamental de meu argumento: a polêmica só existe porque a modificação introduzida no Código criou uma exceção regulatória.

${ }^{18}$ Não conheço nenhuma análise sobre a controvérsia. Baseei-me em notícias publicadas na Internet, onde circulam muito protestos; para o texto do projeto de lei, cf. http://www.senado.gov.br/ MarceloCrivella/projetos/pls6905.htm (consultado em 21.04.2008)

19 Ver o texto da justificativa do projeto em http://www.senado.gov.br/MarceloCrivella/projetos/ pls6905.htm

${ }^{20}$ Cf. artigo e entrevista publicados na Internet: http://www.senado.gov.br/MarceloCrivella/artigos/ caluniaeverdade.htm e http://www.canalcontemporaneo.art.br/brasa/archives/001287.html. (consultados em 21.04.2008)

${ }^{21}$ Várias notícias foram publicadas acerca do "acordo", mas não tive acesso ao seu texto. Minha fonte para o comentário foi a matéria do Estado de São Paulo, 11.05.2007 (http://www.estado.com.br/ editorias/2007/05/11/ger-1.93.7.20070511.13.1.xml).

22 Vale notar que, em 2007, o governo brasileiro rechaçou, embora não totalmente, a idéia do acordo, em nome da laicidade. Nota de novembro de 2008: tivemos a notícia, após a conclusão deste texto, da assinatura do tal acordo entre o Estado brasileiro e o Vaticano durante a viagem do presidente da República à Itália. O acordo precisa ser ratificado pelo Congresso Nacional brasileiro. Em relação aos dois pontos que foram objeto de meu comentário, estão presentes na versão assinada do acordo (arts. 3․ e 6\%.) Para o texto, ver http://www.mre.gov.br/portugues/imprensa/ nota_detalhe3.asp?ID_RELEASE $=6031$

Recebido em abril de 2008

Aprovado em julho de 2008

\section{Emerson Giumbelli (eagi@terra.com.br)}

Professor do Departamento de Antropologia Cultural e do Programa de PósGraduação em Sociologia e Antropologia da Universidade Federal do Rio de Janeiro. 


\section{Resumo:}

Toma-se como problema central especificar as formas pelas quais se configuram relações de reconhecimento do religioso pelo Estado no Brasil no quadro definido pelo regime republicano. Em outras palavras, considerando a laicidade - por causa dela ou apesar dela -, como o Estado foi legitimando a presença do religioso no espaço público. No caso da Igreja Católica, isso ocorreu inicialmente por meio de uma aliança simbólica e material e com a ajuda de um regime jurídico de baixo controle estatal. No caso do espiritismo, ocorreu em meio a uma batalha pela legitimidade de práticas com algum sentido terapêutico. No caso dos cultos afros, envolveu a aceitação de um argumento culturalista. Partindo do delineamento histórico de diferentes modalidades de reconhecimento, busca-se a caracterização do que ocorre atualmente, considerando a presença dos evangélicos no espaço público. De modo geral, trata-se de problematizar a definição de fronteiras no interior do campo religioso e nas relações entre religião, sociedade e Estado no Brasil.

Palavras-chave: laicidade, campo religioso brasileiro, espaço público.

\section{Abstract:}

This paper analyzes the forms of recognition of religion by the State in Brazil in the framework defined by the Republican regime. In other words, considering the secular nature of government - and because or despite it - it analyzes how the State gave legitimacy to a religious presence in public space. In the case of the Catholic Church, this initially took place by means of a symbolic and material alliance and with the help of a legal regime with low government control. In the case of Spiritism, it took place amid the battle for legitimacy of practices with some therapeutic element. In the case of African cults, it involved the acceptance of a culturalist argument. Based on the historic delineation of different modalities of recognition, it seeks to characterize current actions, considering the presence of Protestants in public space. In general, it involves analyzing the definition of frontiers within the religious field and the relations between religion, society and State in Brazil.

Keywords: secularism, Brazilian religious field, public space. 